\title{
Environmental and economic implications of slag disposal practices by the ferrochromium industry: A case study
}

\author{
J Hattingh and JFC Friend* \\ Environmental Engineering Group, Department of Chemical Engineering, University of Pretoria, Pretoria 0002, South Africa
}

\begin{abstract}
A large volume of slag is annually produced by the ferrochromium industry and the slag has historically been dumped without any pollution prevention, control or remediation measures. The slag at the ASSMANG Chrome Machadodorp (ACM) plant in Mpumalanga (where this case study was conducted) contains elements that may pose a significant threat to human life and the environment. The objectives of this study were to assess the composition of the slag produced at the ACM plant and classify the slag in terms of the minimum requirements, as prescribed by the Department of Water Affairs and Forestry (DWAF), and to determine the economic implications of compliance with existing statutory requirements, and critically assess the implementation of the minimum requirements in practice.

According to leachability results for the ACM slag, aluminium (Al), iron ( $\mathrm{Fe})$ and manganese $(\mathrm{Mn})$ have the potential to leach from the slag in excess of the acceptable risk levels. Using the minimum requirements' prescribed methods, the ACM slag was classified based on these three substances as Hazard Rating II. Total elimination of the production of slag is impossible at this stage and disposal on a permitted $\mathrm{H}: \mathrm{H}$ landfill site is currently the final waste management option.

Permitting and construction of an $\mathrm{H}: \mathrm{H}$ landfill site to accommodate all the ACM slag produced over a period of 55 years are conservatively estimated at between R $6.2 \mathrm{~m}$. and R12 m. The cost to remove and dispose of $13 \times 10^{6} \mathrm{t} \mathrm{ACM}$ slag at the Holfontein landfill site is an estimated R5 $900 \mathrm{~m}$. If another permitted H:H landfill site becomes available at Nelspruit, the cost will be reduced to an estimated R4 $600 \mathrm{~m}$.

The DWAF minimum requirements document used for this case study is a useful guideline. However, the document was not compiled for use by a layman and the subsequent application requires careful studying and practice. Furthermore, a number of issues, for example, relevant usage of the two different methods for classification and ascribing a higher hazard rating to substances with high $\mathrm{K}_{\mathrm{oc}}$ values, require clarification.
\end{abstract}

\section{Introduction}

Chromium reduction plants extract chromium $(\mathrm{Cr})$ from chromite ore to produce ferrochromium. Ferrochromium is a mixture of $\mathrm{Cr}$ and $\mathrm{Fe}$ used in the production of stainless steel.

In South Africa, the submerged electrode arc-smelting process is mainly used for the production of ferrochromium. During the smelting process, an $\mathrm{Fe}-\mathrm{Cr}$ rich melt (the ferrochromium product) and a slag (waste containing other residual materials) are produced. A large volume of this slag is produced annually by the ASSMANG Chrome Machadodorp (ACM) plant in Mpumalanga and historically this has been dumped without any pollution prevention, control or remediation measures.

The slag contains elements that may pose a significant threat to human life and the environment, for example, hexavalent $\mathrm{Cr}$, Fe and $\mathrm{Mn}$. It further has the potential to produce leachate and subsequent pollution of surface and groundwater resources.

The objectives of this study are to:

- assess the composition of the slag produced at the ACM plant and classify the slag in terms of the minimum requirements, as prescribed by DWAF,

- determine the economic implications of compliance with existing statutory requirements, and

- critically assess the implementation of the minimum requirements in practice.

* To whom all correspondence should be addressed.

푱(012) 420 3741; fax (012) 362 5173; e-mail: ffriend@eng.up.ac.za Received 14 May 2002; accepted in revised form 29 October 2002.
This study is limited to the slag emanating from the ACM plant and the statutory requirements pertaining to it in South Africa.

\section{Literature survey}

\section{General background}

Several different processes are used for the production of ferrochromium. In South Africa, the submerged electrode arcsmelting process is mainly used. During the submerged electrode arc-smelting process, the chromite ore is blended with carbon-rich material (reductants) and fluxes (coke, char and coal) to produce the feedstock. The feedstock is fed into an electric-arc furnace where it is melted (Papp, 2000).

The smelting process uses electrical energy to melt the feedstock, raising the melt to a temperature at which the mixture will chemically react. The net result of the chemical reaction is that carbon $(\mathrm{C})$ combines with oxygen $(\mathrm{O})$ from the ore to form $\mathrm{CO}$ and $\mathrm{CO}_{2}$ gases that evolve from the melted mixture leaving a $\mathrm{Fe}-\mathrm{Cr}$ rich melt (ferrochromium), as well as a slag (waste material) containing other residual materials. Once enough ferrochromium has been produced, the furnace is opened, permitting the ferrochromium and slag to flow out (Papp, 2000).

Variations in the process, depending on the relevant plant, affect the quality and composition of the product and slag.

\section{ASSMANG Chrome Machadodorp Plant}

The ACM plant is situated in Mpumalanga. Two 30 MVA furnaces and one 24 MVA open-arc furnace are currently used at the ACM plant. 
Ferrochromium is extracted from the $\mathrm{Cr}$ ore to produce the final product. The metal and primary slag are tapped from the furnaces approximately every $2 \mathrm{~h}$. The $\mathrm{Cr}$ is tapped through a furnace tap hole into a ladle and is then cast into silica sand/ferrochromium fines moulds. Primary slag (also termed untreated or unweathered slag), a semi-solid waste still containing ferrochromium and $2 \%$ moisture, is tapped into a slag bell (a big round pot-like container) and processed through a metal-recovery processing (MRP) plant where the slag is crushed, screened and separated from the residual metal through a hydro-jigging process. The metal and slag (now termed final, treated or weathered slag) are separated during this process as a result of their differences in density and the final slag is dumped on site (all future references to slag will refer to final slag).

The ACM plant is currently producing approximately $144000 \mathrm{t}$ of ferrochromium and $175000 \mathrm{t}$ of final slag per year (Hattingh, 2002). An upgrade is planned for the plant, which will increase the slag production to $350400 \mathrm{t}$ per year (Hattingh, 2002).

The existing slag dump at the ACM plant contains $5250000 \mathrm{t}$ of slag and occupies approximately 5 ha. According to a Preliminary Closure Plan study (V3, 2001a), it is estimated that a further $8409600 \mathrm{t}$ of slag will have been produced by the year 2025 and the slag will occupy approximately 40 ha.

Two pollution control dams have been constructed downgradient from the existing slag dump, but no other pollution prevention methods have been installed (V3, 2001b). There are several production and monitoring boreholes on site from which monitoring of groundwater quality is done on a monthly basis. An additional monitoring borehole upstream from ACM has been sunk, to provide background data of groundwater quality. According to the water quality analyses from this borehole, no significant pollution of groundwater resources has occurred.

Once-off surface water quality results indicated no significant pollution of surface water. However, weekly sampling (GCS, 2001) over a period of three months have shown $\mathrm{Cr}^{6+}$ levels, in the two pollution control dams, higher than the SABS drinking water standards. Pollutants in the pollution control dams are considered to be the result of surface runoff from the slag dump.

A geohydrological study (GCS, 2001), indicated that the ACM site is characterised by reddish brown/brown clay, loam soil. The underlying geology consists of greenish fine-grained laminated shales and sub-ordinate mudstone formations of the Pretoria Group. Mostly shale formations were encountered during drilling, with underlying dolerite intersected in places. It is therefore possible that a clay layer underlies the slag dump. The clay layer may be acting as a "liner", preventing possible pollution to the groundwater sources (Hattingh, 2002).

\section{Statutory requirements}

The Minimum Requirements for the Handling, Classification and Disposal of Hazardous Waste (DWAF, 1998), is based on the precautionary principle. This implies that all wastes should be regarded as hazardous where there is any doubt about the potential danger of a waste stream to man or the environment.

In South Africa, the classification of waste in terms of its hazardous characteristics is based on the SABS Code 0228, Identification and Classification of Dangerous Substances and Goods, which was derived from the International Maritime Dangerous Goods (IMDG) Code (DWAF, 1998).

Class 6 of this Code, Poisonous (Toxic) and Infectious Substances, is divided into three danger groups, which relate primarily to transportation and taking into account only the danger

\begin{tabular}{|c|c|c|}
\hline \multicolumn{3}{|c|}{ TABLE 1 } \\
Toxicity criteria \\
\hline LD $_{50}(\mathbf{m g} / \mathbf{k g})$ & LC $_{50}(\mathbf{m g} / \mathbf{l})$ & Hazard rating \\
\hline$<5$ & $<1$ & HRI \\
$5-50$ & $1-10$ & HRII \\
$50-500$ & $10-100$ & HRIII \\
$500-5000$ & $100-1000$ & HRIV \\
\hline
\end{tabular}

to man. In terms of the minimum requirements, this has been extended to take into account potential hazardousness to the ecosystem and specifically groundwater. This extension entails attributing a Hazard Rating (classification) to a waste (DWAF, 1998).

The minimum requirements issued by DWAF provide two methods for the classification of a waste stream. The first method (an initial screening procedure) prescribes a Hazard Rating to a substance, based on its relevant acute mammalian toxicity $\left(\mathrm{LD}_{50}\right)$ and/or acute ecotoxicity $\left(\mathrm{LC}_{50}\right)$, in accordance with Table 1 (DWAF, 1998).

The second method follows a progression path for classification according to certain substance specific criteria, as illustrated in Fig. 1. The second method first assesses whether a waste stream contains substances classified as:

- infectious (a substance which has the potential to provoke infection, allergy or toxic effects),

- a teratogen (a substance which has the capacity to cause birth defects),

- a carcinogen (a substance with the potential to induce cancer), and/or

- a mutagen (a substance with the potential to induce genetic mutations).

The minimum requirements provide lists with recognised teratogens, Class $\mathrm{A} / \mathrm{B}$ and Class $\mathrm{C} / \mathrm{D}$ carcinogens/mutagens for easy reference. The concentration of the specific carcinogenic or mutagenic substance will be the first criteria towards a Hazard Rating for that substance. Thereafter, a substance is rated according to its level (extreme/high/moderate/low) of acute mammalian toxicity $\left(\mathrm{LD}_{50}\right)$ and/or acute ecotoxicity $\left(\mathrm{LC}_{50}\right)$. Finally, a substance is rated according to its environmental fate and exposure (DWAF, 1998). To determine the environmental fate and exposure of a hazardous substance, all properties of the chemical/waste related to exposure within the environment are taken into account.

Properties such as estimated environmental concentration (EEC), biodegradability, accumulation and persistence in the environment are considered (DWAF, 1998).

The Estimated Environmental Concentration (EEC) of a substance represents the exposure by a hazardous substance in a waste, should it enter into the environment (air, water and soil). In a complex waste stream, the EEC of the most hazardous substance in the waste stream will determine the Hazard Rating for the total waste stream (DWAF, 1998).

The minimum requirements (DWAF, 1998) further state that one tenth of the $\mathrm{LC}_{50}$ (the median lethal concentration at which a substance would kill $50 \%$ of aquatic animals tested) should have a limited effect on the aquatic environment and can therefore be considered the concentration at which a substance poses an acceptable low risk to the environment. The relationship $0.1 \times \mathrm{LC}_{50}$ is termed the Acceptable Risk Level (ARL). When EEC is equal 


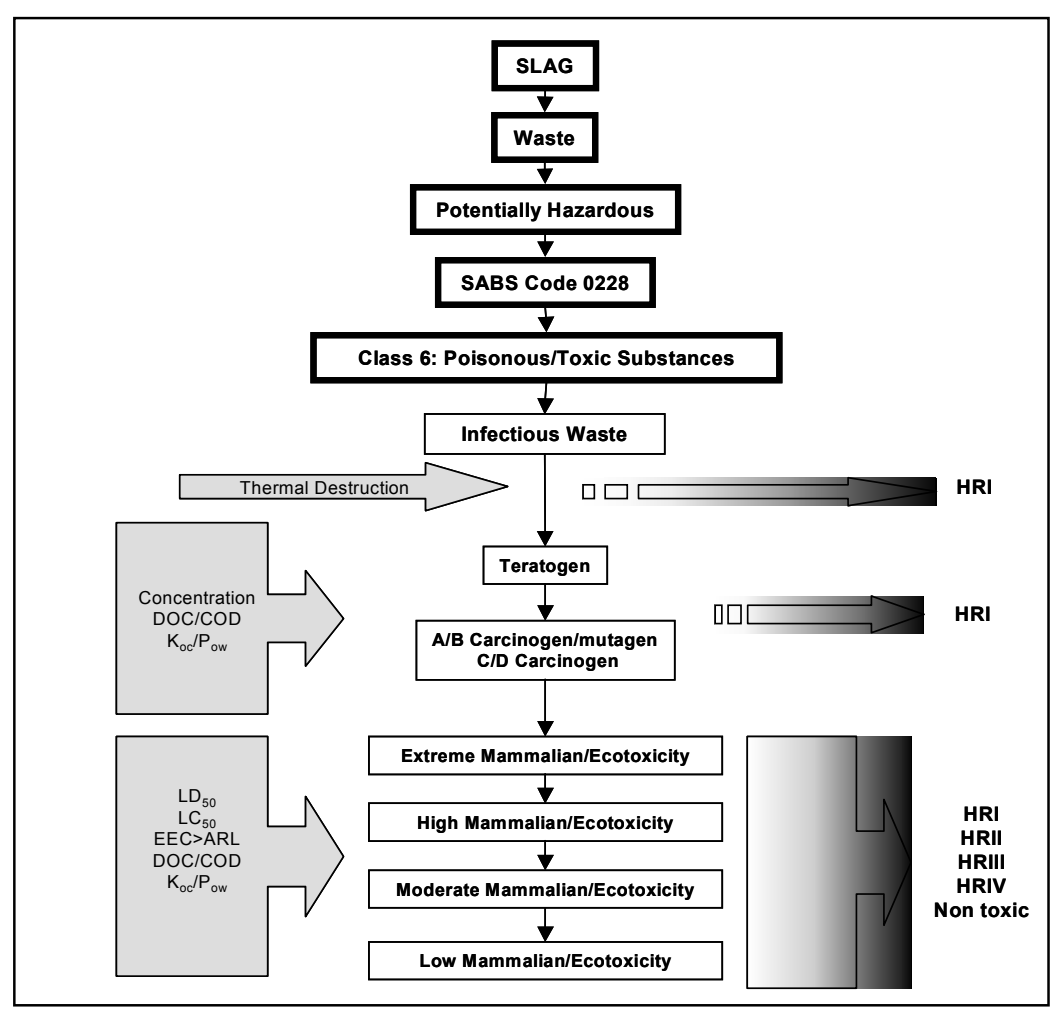

Figure 1

Simplified diagram for determining a Hazard Rating

or less than the ARL, a compound is considered to be a lesser or no threat to the environment (DWAF, 1998).

Biodegradability of a substance is measured as either DOC, the biodegradability of a substance, measured as dissolved oxygen (DO); or COD (chemical oxygen demand), which is expressed as a percentage $(\%)$. The octanol/water partition coefficient $\left(\mathrm{P}_{\text {ow }}\right)$ is used as an index of the bioaccumulation potential of a substance in the food chain, whilst the potential of a substance to bind to soil particles is indicated by its soil absorption coefficient $\left(\mathrm{K}_{\mathrm{oc}}\right) . \mathrm{K}_{\mathrm{oc}}$ relates to the persistence potential of a substance and compounds with a low $\mathrm{K}_{\mathrm{oc}}$ will tend to migrate or leach from the landfill site into the environment, thus placing the environment at risk (DWAF, 1998).

The Hazard Rating, determined by means of either Method 1 or 2 , is used to determine the class of landfill at which a waste is disposed of. Table 2 provides landfill classes for different hazard ratings (DWAF, 1998).

\begin{tabular}{|c|c|c|}
\hline \multicolumn{3}{|c|}{$\begin{array}{c}\text { TABLE } 2 \\
\text { Landfill classes }\end{array}$} \\
\hline $\begin{array}{c}\text { Hazard } \\
\text { rating }\end{array}$ & Description & Landfill class \\
\hline I & Extreme Hazard & $\mathrm{H}: \mathrm{H}$ \\
\hline II & High Hazard & $\mathrm{H}: \mathrm{H}$ \\
\hline III & Moderate Hazard & $\mathrm{H}: \mathrm{h}$ \\
\hline IV & Low Hazard & $\mathrm{H}: \mathrm{h}$ \\
\hline
\end{tabular}

\section{Composition and classification of ACM slag}

A composition analysis was conducted on the ACM slag during leachability tests in 2000 and selected results are presented in Table 3 (Feralloys, 2000).

These substances may cause a variety of adverse effects in humans and a wide diversity of organisms and are consequently deemed hazardous.

Based on the DWAF (1998) definitions, the ACM slag is classified as a waste and is presumed hazardous. Consequently, the classification of the slag is done according to the minimum requirements (DWAF, 1998), as illustrated in Fig. 1 (Method 2).

The ECC of a substance is based on the total concentration of the substance in an aquatic environment. However, not all hazardous substances in a waste stream will necessarily leach out into the environment, therefore the Toxicity Characteristic Leaching Procedure (TCLP) and/or the Acid Rain tests are used to determine the actual amount of a substance that will leach out of the waste stream (DWAF, 1998).

Leachability of the components in the ACM slag was determined by using the Acid Rain test, as stipulated by the minimum requirements (DWAF, 1998). Selected results from the tests are provided in Table 4 (Feralloys, 2000).

The ACM laboratories performed the above leachability tests and their results were compared and confirmed by ECC (2001a; 2001b), who used both the TCLP and Acid Rain tests for the classification process. These results (at $\mathrm{pH} 5.03$ and 5.65 respectively) are provided in Table 5.

According to the leachability results $\mathrm{Al}, \mathrm{Fe}$ and $\mathrm{Mn}$ have the potential to leach from the slag in excess of the acceptable risk levels. Classification of the slag will therefore be based on the classification of these three substances. Under the specific chemical

TABLE 3

Concentration of selected elements in the ACM slag

\begin{tabular}{|l|c|c|c|c|c|c|c|c|}
\hline Element & $\mathbf{A l}$ & $\mathbf{C r}$ & $\mathbf{C r}^{6+}$ & $\mathbf{F e}$ & $\mathbf{M g}$ & $\mathbf{M n}$ & $\mathbf{N i}$ & $\mathbf{V}$ \\
\hline Final slag & 85.9 & 1.7 & 0.3 & 182.0 & 120.6 & 8.9 & 2.9 & 0.7 \\
\hline
\end{tabular}

TABLE 4

Leachate elemental analysis

\begin{tabular}{|l|c|c|c|c|c|c|c|c|}
\hline Element & $\mathbf{A l}$ & $\mathbf{C r}$ & $\mathbf{C r}^{6+}$ & $\mathbf{F e}$ & $\mathbf{M g}$ & $\mathbf{M n}$ & $\mathbf{N i}$ & $\mathbf{V}$ \\
\hline ARL & 0.39 & 4.7 & 0.02 & 9.0 & - & 0.30 & - & 1.30 \\
Slag sample & 4.30 & 0.09 & 0 & 9.1 & 6.03 & 0.45 & 0.14 & 0.04 \\
\hline
\end{tabular}

Units in ppm.

ARL = Acceptable Risk Level (DWAF, 1998). 
TABLE 5

Leaching results of the treated slag

\begin{tabular}{|l|c|c|c|c|c|c|c|c|c|}
\hline Description & Test & Al & $\mathbf{C r}$ & $\mathbf{C r}^{6+}$ & $\mathbf{F e}$ & $\mathbf{M g}$ & $\mathbf{M n}$ & $\mathbf{N i}$ & $\mathbf{V}$ \\
\hline ARL & - & 0.39 & - & 0.02 & 9.00 & - & 0.30 & 1.14 & 1.3 \\
Slag sample 1 & TCLP & 0.7 & 1.1 & $<0.05$ & 70 & 7.00 & 0.65 & 0.55 & $<0.07$ \\
Slag sample 2 & Acid rain & $<0.08$ & $<0.04$ & $<0.05$ & 39 & 7.6 & 1.1 & 0.35 & $<0.07$ \\
Slag sample 3 & TCLP & 1.1 & 1.1 & $<0.04$ & 66 & 14 & 1.2 & 0.79 & $<0.07$ \\
Final pH & TCLP & 5.03 & & & & & & & \\
Final pH & Acid rain & 5.65 & & & & & & & \\
\hline
\end{tabular}

Units in $\mathrm{mg} / \ell$.

ARL = Acceptable Risk Level (DWAF, 1998).

conditions prevalent in the slag dump, aluminium chloride $\left(\mathrm{AlCl}_{3}\right), \mathrm{Fe}$ and manganese chloride $\left(\mathrm{MnCl}_{2}\right)$ will be the most likely forms of these substances present in the slag and are hence used in determining the Hazard Rating of the waste stream (Hattingh, 2002).

Table 6 provides specific information on the relevant concentration (Feralloys, 2001), solubility (Lide, 1994; ATSDR, 2001; Hattingh, 2002), $\mathrm{LD}_{50}$ and $\mathrm{LC}_{50}$ values of the three leachable substances in the ACM slag (Richardson, 1992; DWAF, 1998; ATSDR, 2001).

With reference to Table $7, \mathrm{AlCl}_{3}, \mathrm{Fe}$ and $\mathrm{MnCl}_{2}$ are subsequently classified

TABLE 6

Specific information on the three substances

\begin{tabular}{|l|c|c|c|c|}
\hline Description & Unit & $\mathbf{A I C l}_{3}$ & $\mathbf{F e}$ & $\mathbf{M n C l}_{2}$ \\
\hline Concentration & $\mathrm{ppm}$ & 85.9 & 182.0 & 8.9 \\
Solubility & $\mathrm{ppm}$ & 699000 & insoluble & 723000 \\
$\mathrm{LD}_{50}$ & $\mathrm{mg} / \mathrm{kg}$ & 370 & 30000 & 412 \\
$\mathrm{LC}_{50}$ & $\mathrm{mg} / \ell$ & 100.0 & 90.0 & 3.0 \\
\hline
\end{tabular}

according to the minimum requirements (DWAF, 1998). The progression steps followed according to Method 2 for $\mathrm{Fe}$ are illustrated in Fig. 2.

Step 1-3

$\mathrm{Fe}$ is not infectious, nor is it classified as a teratogen or carcinogen/ mutagen.

\section{Step $4-8$}

The $\mathrm{LD}_{50}$ of $\mathrm{Fe}$ is $30000 \mathrm{mg} / \mathrm{kg}$ and Fe therefore does not exhibit extreme, high or moderate mammalian acute toxicity. The $\mathrm{LC}_{50}$ of

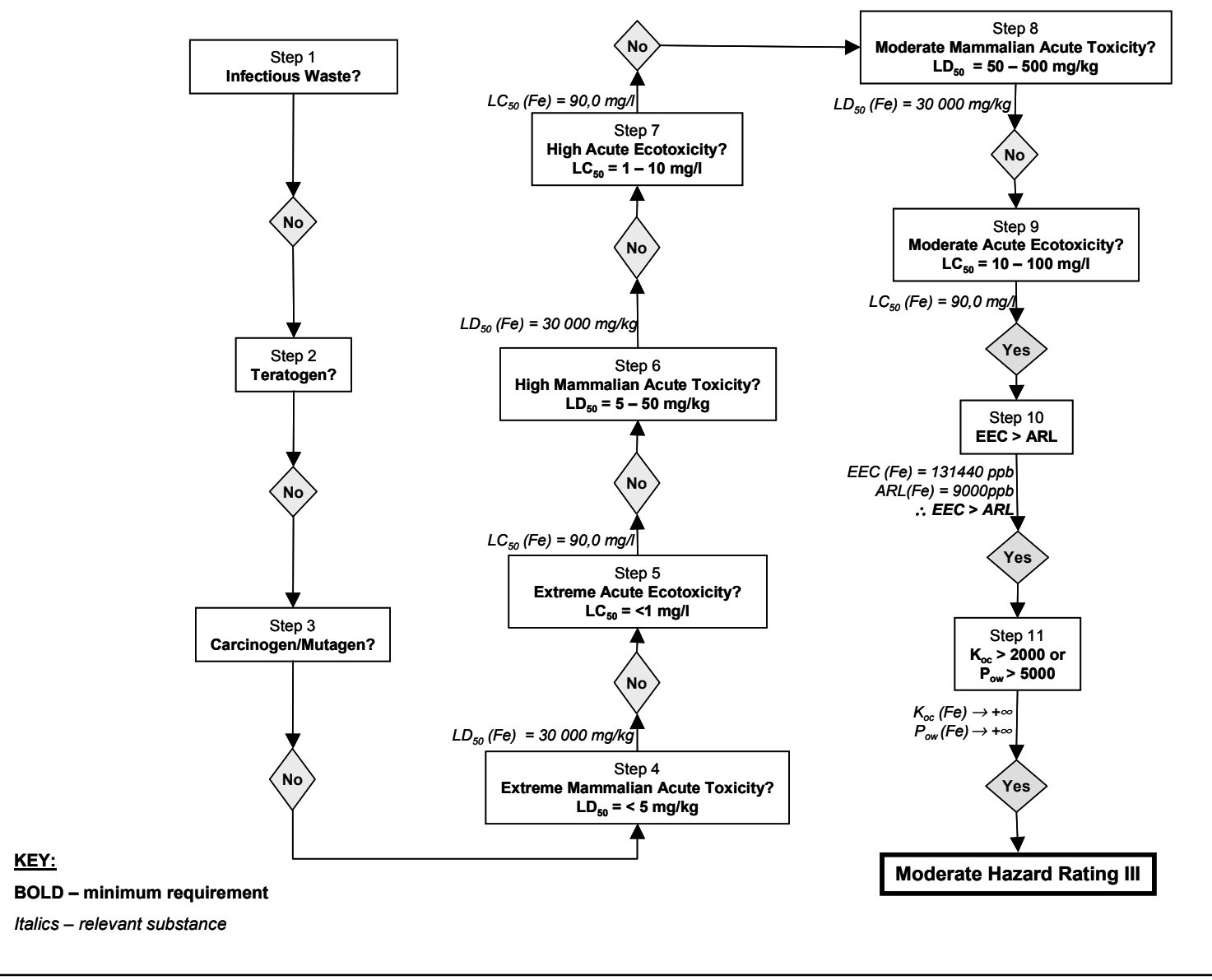

Figure 2

Hazard classification of $\mathrm{Fe}$ 


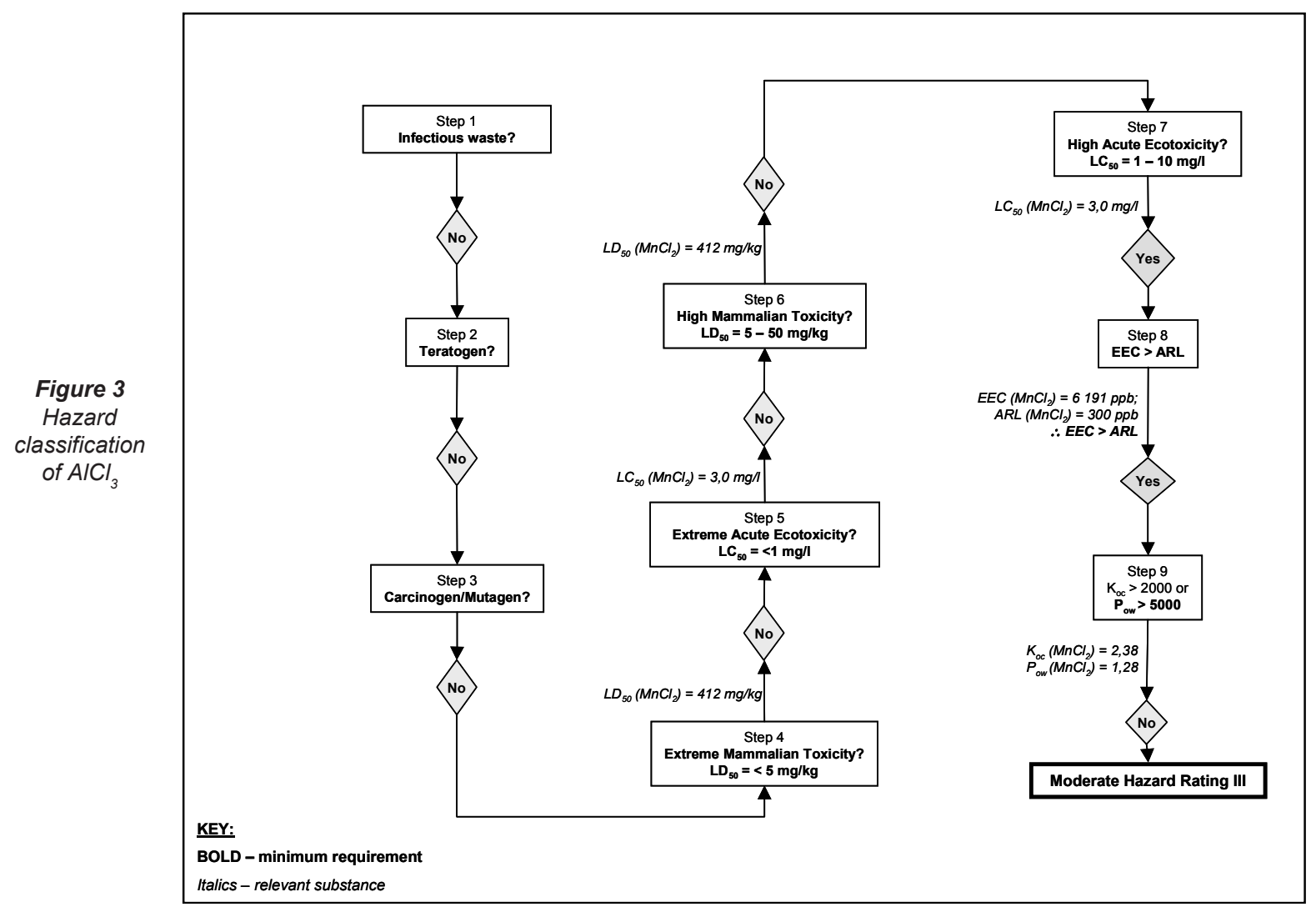

Fe is higher than $10 \mathrm{mg} / \ell$ and therefore Fe cannot be classified as a substance with extreme or high acute ecotoxicity.

\section{Step 9}

The $\mathrm{LC}_{50}$ of $\mathrm{Fe}$ is $90 \mathrm{mg} / \mathrm{l}$ and therefore $\mathrm{Fe}$ is classified as a substance with moderate acute ecotoxicity.

\section{Step 10}

The Acceptable Risk Level $\left(0,1 \times \mathrm{LC}_{50}\right)$ for $\mathrm{Fe}$ is $9.0 \mathrm{mg} / \mathrm{l}$ or $9000 \mathrm{ppb}$.

The Estimated Environmental Concentration (EEC) of the substance can be calculated from: EEC $(\mathrm{ppb})=$ dose $(\mathrm{g} / \mathrm{ha} / \mathrm{month})$ $\times 0.66$, where dose represents the total amount in grams of the substance in the waste to be disposed of on 1 ha of the disposal site per month (DWAF, 1998). In order to determine the dose for disposal, it is assumed that the ACM slag will occupy similar areas for disposal as for the present and estimated areas, and that disposal will take place over 24 years.

Concentration of iron in the waste stream is $182.0 \mathrm{mg} / \mathrm{kg}$ (Table 3) and the amount of ACM slag to be disposed of is $13659600 \mathrm{t}$ (Hattingh, 2002).

Dose of $\mathrm{Fe}=13659600 \mathrm{t}$ at $182 \mathrm{mg} \mathrm{Fe} \mathrm{per} \mathrm{kg}$ for 24 years and $45 \mathrm{ha}$

$$
=191825 \mathrm{~g} / \mathrm{ha} \cdot \mathrm{month}
$$

Consequently, the EEC is $126605 \mathrm{ppb}(0.66 \times 191825 \mathrm{ppb})$ and is higher than the ARL.

\section{Step 11}

From DWAF (1998) the persistence potential $\left(\mathrm{K}_{\mathrm{oc}}\right)$ of the Fe can be calculated from:

$\log K_{o c}=3.6-(0.55 \times \log S)$, where $\mathrm{S}$ (solubility) = insoluble $(\therefore 0 \mathrm{ppm})$.
With $\log \mathrm{S} \rightarrow-\infty, \log \mathrm{K}_{\mathrm{oc}} \rightarrow+\infty$ and $\mathrm{K}_{\mathrm{oc}} \rightarrow+\infty$, it follows that $\mathrm{K}_{\mathrm{oc}} \gg 2000$.

From DWAF (1998) the accumulation potential $\left(\mathrm{P}_{\text {ow }}\right)$ of Fe can be calculated from:

$\log P_{\text {ow }}=4.5-(0.75 \times \log S)$, where $\mathrm{S}$ (solubility) = insoluble $(\therefore 0 \mathrm{ppm})$.

With $\log \mathrm{S} \rightarrow-\infty, \log \mathrm{P}_{\text {ow }} \rightarrow+\infty$ and $\mathrm{P}_{\text {ow }} \rightarrow+\infty$, it follows that $\mathrm{P}_{\text {ow }}$ > 5000

According to the persistence and accumulation potential of Fe, it is classified as a moderate Hazard Rating III. (With the ecotoxicity of Fe $\left(\mathrm{LC}_{50}\right)$ equal to $90 \mathrm{mg} / \mathrm{l}$, a similar Hazard Rating of III is obtained based on Table 1.)

The Hazard Rating for $\mathrm{AlCl}_{3}$ and $\mathrm{MnCl}_{2}$ are determined similarly and illustrated in Figs. 3 and 4.

Figure 3 indicates a Hazard Rating III for $\mathrm{MnCl}_{2}$, if the classification is done according to Method 2. However, when using Method 1 (see Table 1) $\mathrm{MnCl}_{2}$ has a Hazard Rating II. Consequently, the higher Hazard Rating of II is used. Table 7 provides a summary of the classification of the three substances.

\section{Economic implications of compliance with statutory requirements}

The slag is classified as a high Hazard Rating II and according to Table 2 the slag has to be disposed of on a $\mathrm{H}: \mathrm{H}$ landfill site. Two options are available to comply with the current statutory requirements, namely either construction and permitting of an $\mathrm{H}: \mathrm{H}$ landfill site at ACM, or disposal of the slag at an existing permitted $\mathrm{H}: \mathrm{H}$ landfill site.

Based on initial evaluations, the permitting and construction of an $\mathrm{H}: \mathrm{H}$ landfill site to accommodate all the ACM slag produced over a period of 55 years are conservatively estimated by V3 (2001a) at between R6.2 m. and R12 m. If sufficient clay layer is 

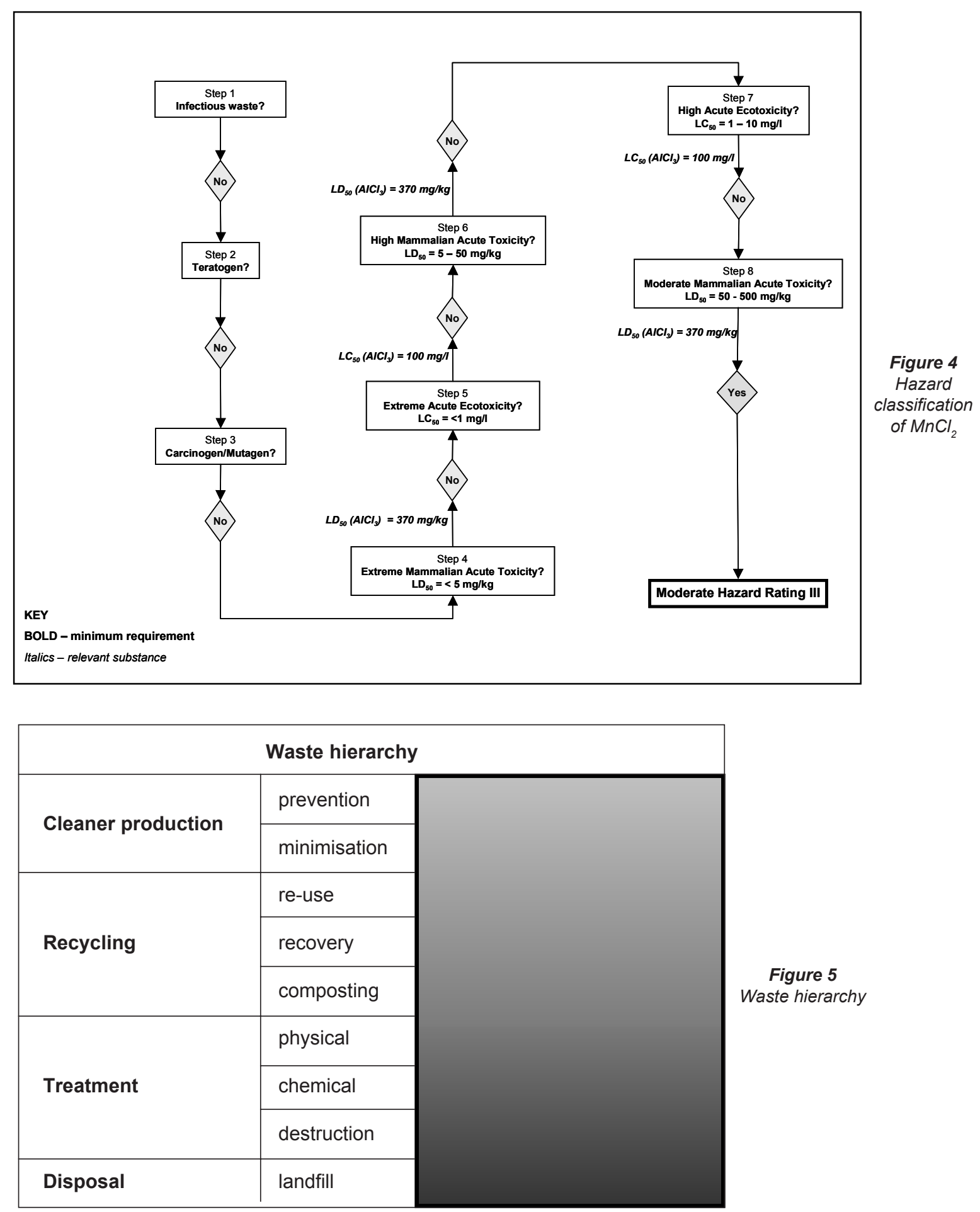

underlying the slag dumpsite, the estimated cost for construction will be lower, however, the site still requires permitting. Additional costs will be operation of the site, capping and final rehabilitation (V3, 2001a).

The nearest permitted $\mathrm{H}: \mathrm{H}$ landfill site is situated at Holfontein, which is approximately $350 \mathrm{~km}$ from Machadodorp. Another $\mathrm{H}: \mathrm{H}$ landfill site is planned in Nelspruit, which is approximately $100 \mathrm{~km}$ from ACM. The transportation and disposal costs are typically 1000 times more expensive (R 5900 m for Holfontein; R 4600 m for Nelspruit) and is not considered further (Hattingh, 2002).

\section{Alternative options}

In line with the National Waste Management Strategy (DEAT, 1999) and other national policies, waste must be managed in accordance with the hierarchy of waste management, as illustrated in Fig. 5 (DEAT, 1999).

Apart from the final option of disposal through landfill, the only other option viable at present is that of re-use of the slag. According to ECC (2001a) and other sources, the re-use of slag has been investigated in several countries. Some of the alternative options are: 


\begin{tabular}{|c|c|c|c|}
\hline \multicolumn{4}{|c|}{$\begin{array}{c}\text { TABLE } 7 \\
\text { Classification of substances }\end{array}$} \\
\hline Criteria & $\mathrm{AlCl}_{3}$ & $\mathrm{Fe}$ & $\mathrm{MnCl}_{2}$ \\
\hline Infectious & Negative & Negative & Negative \\
\hline Teratogen & Negative & Negative & Negative \\
\hline Carcinogen & Negative & Negative & Negative \\
\hline Acute toxicity & $\begin{array}{c}\mathrm{LD}_{50}=222 \mathrm{mg} / \mathrm{kg} \\
\mathrm{LC}_{50}=100 \mathrm{mg} / \ell \\
\mathrm{EEC}>\mathrm{ARL} \\
\text { N/A } \\
\text { N/A }\end{array}$ & $\begin{array}{c}\mathrm{LD}_{50}=30000 \mathrm{mg} / \mathrm{kg} \\
\mathrm{LC}_{50}=90 \mathrm{mg} / \ell \\
\mathrm{EEC}>\mathrm{ARL} \\
\mathrm{K}_{\text {oc }}>2000 \\
\mathrm{P}_{\text {ow }}>5000\end{array}$ & $\begin{array}{c}\mathrm{LD}_{50}=412 \mathrm{mg} / \mathrm{kg} \\
\mathrm{LC}_{50}=3 \mathrm{mg} / \ell \\
\mathrm{EEC}>\mathrm{ARL} \\
\mathrm{K}_{\mathrm{oc}}<2000 \\
\mathrm{P}_{\text {ow }}<5000\end{array}$ \\
\hline Hazard Rating & III & III & II \\
\hline
\end{tabular}

- road building,

- use as slagment in the cement industry, and

- use as a replacement for magnetite in the mining industry.

ASSMANG (Feralloys, 2000) also investigated the possible use of the slag as heavy medium in the coal mining industry.

\section{Critical assessment of the minimum requirements}

The minimum requirements provide two methods for the classification of a waste stream. However, no background as to the origin and proposed or preferential use of these two methods are provided.

The three leachable substances in the ACM slag have been classified by using both these methods. Except for $\mathrm{MnCl}_{3}$ (Hazard Rating II vs III), the two methods provided the same relevant Hazard Rating.

Appendix 8.1 of the minimum requirements indicates that the soil absorption coefficient $\left(\mathrm{K}_{\mathrm{oc}}\right)$ of a substance indicates its potential for chemically binding with soil particles. A compound with a low $\mathrm{K}_{\mathrm{oc}}$ (less than 50) will generally tend to migrate or leach from the landfill and subsequently pose a potential negative impact on the environment (DWAF, 1998). A waste stream is, inter alia, classified based on those substances that leach from the relevant waste stream, indicated by low $\mathrm{K}_{\mathrm{oc}}$ values. However, it is unclear when using the minimum requirements to classify the waste, why substances with a high $\mathrm{K}_{\mathrm{oc}}$ (larger than 2000, indicating substances that tend not to leach from a landfill into the environment), have a higher Hazard Rating than substances with a low $\mathrm{K}_{\mathrm{oc}}$ value.

Another ambiguity in using the minimum requirements to classify a waste is which form of the substance is to be used for the classification. Under different conditions, different forms of a specific substance may exist with differing solubility values and toxicity characteristics. The minimum requirement does not make provision for the various species of some of the substances that may exist under different conditions. For example, the hazardous waste classification tables in Appendix 9.2 of the minimum requirements only provide information for $\mathrm{Fe}$ and no information is provided for the various other forms of Fe that may be encountered.

\section{Conclusions}

Using the minimum requirements' prescribed methods, the ACM slag is classified as a Hazard Rating II waste with associated disposal requirements. If landfilling is chosen as the final waste management option, the slag must be disposed of on a permitted $\mathrm{H}: \mathrm{H}$ landfill. The permitting and construction of an $\mathrm{H}: \mathrm{H}$ landfill site is costly, with transportation and disposal to an existing $\mathrm{H}: \mathrm{H}$ landfill even more expensive. The permitting and construction of an $\mathrm{H}: \mathrm{H}$ landfill site to accommodate all the ACM slag produced are estimated at R $6.2 \mathrm{~m}$. Transportation and disposal to the Holfontein $\mathrm{H}: \mathrm{H}$ landfill site is an estimated R $5900 \mathrm{~m}$.

Total elimination of the production of slag is impossible at this stage. The environmentally acceptable method will be to minimise the slag, at present the only option available is that of re-use. Although some re-use options seem feasible, limited information is available about the environmental impact of these options.

The minimum requirements document is a useful guideline. However, the document does not allow for use by a layman and the subsequent application requires careful studying and consultation. Furthermore, a number of issues, for example, relevant usage of the two different methods for classification and ascribing a higher Hazard Rating to substances with high $\mathrm{K}_{\mathrm{oc}}$ values, require clarification.

\section{Recommendations}

It is recommended that alternative disposal options be considered for the slag, rather than insisting on disposal by landfill. Further research into present re-use options and other alternatives for suitable disposal of the slag are recommended.

The minimum requirements should be revised to include a thorough explanation on which method to use under which circumstances for the classification of a waste. The list of substances in Appendix 9.2 should be expanded to include the various forms of a substance that might be found and are deemed hazardous.

The list of substances can be made easily accessible through a database available on the Internet, with a facility to update the records as information becomes available. The $\mathrm{K}_{\mathrm{oc}}$ issue with regard to higher $\mathrm{K}_{\mathrm{oc}}$ values implying higher Hazard Ratings requires further investigation and clarification. 


\section{Acknowledgements}

ASSMANG Chrome Machadodorp plant is gratefully acknowledged for their permission to use their plant, the information provided and permission to publish this paper.

\section{References}

ATSDR (AGENCY FOR TOXIC SUBSTANCES AND DISEASE REGISTRY) (2001) Manganese, http://www.atsdr.cdc.gov/ tfacts151.html [23 September 2001].

DEAT (DEPARTMENT OF ENVIRONMENTAL AFFAIRS \& TOURISM) (1999) National Waste Management Strategies and Action Plans: Strategy Formulation Phase. Version C. DEAT, Pretoria.

DWAF (DEPARTMENT OF WATER AFFAIRS AND FORESTRY) (1998) Minimum Requirements for the Handling, Classification and Disposal of Hazardous Waste ( $2^{\text {nd }}$ edn.). DWAF, Pretoria.

ECC (ENVIRONMENTAL AND CHEMICAL CONSULTANTS CC) (2001a) The Ferro Alloy Producers Association: Study into the Leaching of Ferrochromium Slag and its Classification according to the Minimum Requirements. Confidential Report. Randburg.

ECC (ENVIRONMENTAL AND CHEMICAL CONSULTANTS CC) (2001b) Feralloys Ltd., Chrome Division, Machadodorp: Study into the Leaching of Ferrochromium Slag and its Classification according to the Minimum Requirements. Confidential Report. Randburg.
FERALLOYS LIMITED - CHROME DIVISION (2000) Test work regarding $\mathrm{Cr}^{6+}$ in belt filter slag and its magnetic behaviour. Confidential Report. Feralloys Ltd, Machadodorp.

FERALLOYS LIMITED - CHROME DIVISION (2001) Hexavalent Chromium Leaching - Acid Rain Test. Confidential Report. Feralloys Ltd, Machadodorp.

GCS (GROUNDWATER CONSULTING SERVICES) (2001) Geohydrological Study - Feralloys Limited. Confidential Report. GCS, Nelspruit.

HATTINGH J (2002) Environmental and Economic Implications of Slag Disposal by the Ferrochromium Industry: A Case Study. Project Report, Dept. of Chem. Eng., Univ. of Pretoria, Pretoria.

LIDE DR (1994) CRC Handbook of Chemistry and Physics ( $75^{\text {th }}$ edn.) CRC Press, Inc. Florida.

PAPP J (2000) Chromium. US Geological Survey. Chromium Association. http://www.chromium-asoc.com/thcrfl.htm [23 October 2000].

RICHARDSON ML (1992) The Dictionary of Substances and their Effects. 1 (A - B). Royal Society of Chemistry, London.

V3 (V3 CONSULTINGENGINEERS) (2001a) Feralloys Limited: Closure Plan. Confidential Report. V3, Pretoria.

V3 (V3 CONSULTING ENGINEERS) (2001b) Feralloys Limited: Water Management Report: Prepared as part of the license application for the abstraction of additional water. Confidential Report. V3, Pretoria. 